\title{
Studi Observasi Efektifitas Penggunaan Permainan To The Left dalam Pembelajaran Biologi Kelas VIII di MTs 1 Atap Mlarik Ngawi
}

\author{
Sri Utami $^{1}$, Frendy Oktaris Whidayat ${ }^{2}$, R. Bekti Kiswardianta ${ }^{3}$ \\ 1,2,3 Program Studi Pendidikan Biologi, Fakultas Keguruan dan Ilmu Pendidikan, Universitas PGRI \\ Madiun \\ Email: ${ }^{1}$ sriutami@unipma.ac.id; ${ }^{2}$ frendi_oktaris_w@yahoo.co.id
}

\begin{abstract}
Abstrak
Penelitian bertujuan untuk mengetahui efektifitas penggunaan permainan To The Left dalam pembelajaran biologi siswa kelas VIII MTs 1 Atap Mlarik Ngawi tahun pelajaran 2015/2016 ditijau dari segi keterlaksanaan RPP, aspek kognitif , afektif dan psikomotorik siswa, serta Respon siswa, guru dan kepala sekolah. Penelitian ini merupakan Studi Obsevasi terhadap efektifitas penerapan permainan To The Left yang telah diaplikasikan dalam pembelajaran di kelas VIII MTs 1 Atap Mlarik Ngawi sejak 2013, tetapi belum pernah diamati dan dianalisi tinggkat efektifitasnya. Studi Observasi dilaksanakan selama 5 bulan yaitu Februari-Juni 2016 dengan menggunakan lembar pengamatan. Observasi yang dilakukan meliputi: observasi keterlaksanaan pembelajaran/RPP, observasi dan analisis aspek afektif dan psikomotorik siswa selama proses PBM, angket respon siswa, analisis hasil ulangan harian, dan analisi hasil UTS, lembar panduan wawancara untuk guru biologi kelas VIII dan kepala sekolah. Data penelitian menunjukan bahwa: setiap tahab pembelajaran dalam RPP terlaksana dengan baik dan benar. Siswa menunjukan antusias yang tinggi, keterampilan mengemukakan pendapat dan bertanya yang baik, disiplin, komunikatif dan menghargai pendapat orang lain dalam pembelajaran. Respon siswa terhadap pembelajaran dengan permainan To The Left yang digali menggunakan angket tertutup dari 28 responden menunjukan bahwa efektifitas permainan To The Left adalah 841: $1120 \times 100 \%=75,08 \%$ termasuk kreteria cukup baik. Respon guru dan kepala sekolah terhadap pembelajaran dengan permainan To The Left yang diambil dengan teknik wawancara adalah pembelajaran dinilai efektif dapat menimbulkan rasa ketertarikan, keceriaan dan kegembiraan siswa dalam pembelajaran. Data nilai rata-rata ulangan harian dari 28 siswa sebanyak 21 siswa (75\%) tuntas dan 7 siswa (25\%) tidak tuntas, sedangkan untuk nilai UTS 16 siswa $(57,2 \%)$ tuntas dan 12 siswa $(42,8 \%)$ tidak tuntas. Dapat disimpulkan bahwa permainan to the left cukup efektif apabila dilihat dari pencapaian rata-rata nilai ulangan harian yang didapat, dan kurang efektif apabila dilihat dari nilai UTS. Hal ini dikarenakan materi UTS adalah materi IPA yaitu meliputi biologi, fisika dan kimia yang tidak hanya diajarkan dengan permainan to the left tetapi dengan metode-metode yang biasa dilakukan misalnya penugasan dengan LKS dan ceramah, atau praktikum tanpa ada persentasi laporan hasil praktikum. Kemudian disarankan untuk pembelajaran selanjutnya perlu adanya perbaikan RPP pada tiap fase PBM, dan diterapkan untuk kurikulum K-13..
\end{abstract}

Kata kunci: Permainan To The Left; Kognitif; Afektif; Psikomotorik

\section{Obsevation Study Of Effectiveness Of The Game To The Left In Learning VIII Class Biology in MTS 1 Atap Mlarik Ngawi}

\begin{abstract}
The aim of this research is to know the effectiveness of To The Left game in biology teaching of VIII class of MTs 1 Atap Mlarik Ngawi in 2015/2016 academic year in terms of RPP implementation, cognitive, affective and psychomotor aspect of students, and student's
\end{abstract}


response, teacher and principal. This study is an Obsevation Study on the effectiveness of To The Left game application which has been applied in learning in class VIII MTs 1 Atap Mlarik Ngawi since 2013, but has never been observed and analyzed because of its effectiveness. The observation study was conducted for 5 months from February to June 2016 using the observation sheet. The observations included: observation of learning / RPP, observation and analysis of students' affective and psychomotor aspects during the PBM process, student response questionnaires, daily test results analysis, and UTS result analysis, interview guide sheets for grade VIII biology teachers and principals. Research data shows that: every learning stage in RPP is done properly and correctly. Students show high enthusiasm, skill to express opinions and ask good, discipline, communicative and appreciate the opinions of others in learning. Student responses to learning with the game To The Left excavated using a closed questionnaire of 28 respondents showed that the effectiveness of the game To The Left is 841: $1120 \times 100 \%=75.08 \%$ including good enough criteria. Teacher and principal's response to learning with the To The Left game taken with interview techniques is that effective learning can lead to a sense of interest, joy and excitement for students in learning. Data on average daily average score of 28 students were 21 students (75\%) complete and 7 students (25\%) incomplete, while for UTS score of 16 students $(57,2 \%)$ complete and 12 students $(42,8 \%)$ not complete. It can be concluded that the game to the left is quite effective when viewed from the average achievement of the daily test score obtained, and less effective when viewed from the value of UTS. This is because the UTS material is a science material that includes biology, physics and chemistry that is not only taught by the game to the left but with the usual methods such as assignment with LKS and lectures, or practicum without any percentage of practice report. It is then suggested that further learning needs improvement of RPP in each PBM phase, and applied to the K-13 curriculum.

Keywords: Games To The Left; Cognitive; Affective; Psychomotor.

\section{PENDAHULUAN}

Berdasarkan pengalaman dan pengamatan terhadap proses pembelajaran yang telah dilaksanakan selama ini, maka Guru biologi di MTs 1 Atap Mlarik Ngawi menyadari bahwa perlu adanya perubahan dalam metode dan model pembelajaran yang telah dilaksanakan. Hal itu dikarenakan suasana belajar yang kurang menyenangkan dan belum menyentuk semua ranah kompetensi siswa baik kognitif, afektif dan psikomotorik serta ketuntasan belajar yang belum maksimal. Kemudian guru biologi di MTs 1 Atap Mlarik Ngawi mencoba menerapkan Pembelajaran dengan permainan To The Left mulai akhir tahun ajaran 2013 untuk mengatasi permasalahan diatas. Pembelajaran dengan permainan To The Left yang telah dilaksanakan belum pernah di evaluasi tingkat keberhasilannya. Rencana pembelajaran dan silabus yang dijalankan guru juga belum pernah dinilai tingkat keterlaksanaannya, aktifitas siswa selama proses pembelajaran juga belum diamati dan belum terukur keaktifannya. Ketercapaian tujuan hanya dilihat guru dari sisi kognitif, sedangkan ranah afektif dan ranah psikomotorik belum diukur. Berdasarkan teori yang ada, seharusnya melalui pembelajaran kooperatif dengan permainan To The Left ketercapaian pembelajaran akan lebih tinggi karena siswa akan lebih aktif dalam menyelesaikan pertanyaan dan bertukar pendapat. Siswa dapat mencari informasi sendiri selain mendengarkan dari guru. Oleh karena itu kami berkerjasama untuk melakukan observasi dan analisis keefektifan pembelajaran dengan permainan To The Left yang telah diterapkan di MTs 1 Atap Mlarik Ngawi.

Penelitian ini akan mengevaluasi proses persiapan, pelaksanaan dan hasil pembelajaran. Ketersediaan perangkat pembelajaran, aktifitas siswa dan aktifitas guru akan diamati kesesuaiannya dengan RPP. Hasil pembelajaran akan diukur dari 
ranah kognitif, afektif dan psikomotorik yang sesuai dengan materi ajar. Respon siswa akan diamati dengan lembar angket respon siswa dan kendala yang dihadapi guru. Melalui pengamatan semua aspek tersebut maka diharapkan efektifitas pembelajaran biologi dengan permainan To The Left akan benarbenar terukur.

Belajar merupakan proses internal yang kompleks. Yang terlibat dalam proses internal tersebut adalah seluruh mental yang meliputi ranah- ranah kognitif, afektif dan psikomotorik (Dimyati dan Mudjiono, 2002: 18). Sedangkan menurut Heri Rahyubi (2012: 233) berpendapat bahwa Pembelajaran merupakan suatu sistem yang terdiri dari berbagai komponen yang saling berhubungan satu dengan yang lain. Kompetensi tersebut meliputi: tujuan pembelajaran, kurikulum, guru, siswa, materi, metode, media, dan evaluasi. Pelaksanaan pembelajaran adalah operasionalisasi dari perncanaan pembelajaran yang sudah dibuat. Oleh karenanya dalam pelaksanaannya akan sangat tergantung pada bagaimana perencanaan pengajaran sebagai operasionalisasi dari sebuah kurikulum.

Pembelajaran sains khususnya Biologi selama ini dipandang sebagai ilmu yang memerlukan kegiatan berupa percobaan untuk memahaminya, sehingga metode eksperimen sering dijadikan pilihan dalam melaksanakan pembelajaran Biologi. Metode dengan menggunakan permainan juga dapat diterapkan sehingga siswa terlibat aktif pada proses pembelajaran dan memberikan efek positif terhadap kualitas interaksi serta komunikasi yang berkualitas, dapat memotivasi siswa untuk meningkatkan prestasi belajar. Siswa menjadi lebih kreatif dalam menemukan informasi sendiri tanpa bergantung dari informasi yang diberikan oleh guru. Pada akhirnya siswa akan lebih memahami dan mengimplementasikan isi pelajaran yang diterimanya, dapat juga melatih kemampuan siswa dalam meneliti, menjelaskan fenomena, dan memecahkan masalah secara ilmiah. Suchman (dalam Hamzah: 2007, 15).
Menurut Johnson (dalam Isjoni, 2010: 45) mengemukakan bahwa Coopetive adalah mengerjakan sesuatu bersama-sama dengan saling membantu satu sama lainya sebagai satu tim untuk mencapai tujuan bersama. Cooperative learning berarti juga belajar bersama-sama, saling membantu antara yang satu dengan yang lain dalam belajar dan memastikan setiap orang dalam kelompok mencapai tujuan atau tugas yang telah ditentukan sebelumnya.

Menurut Ibrahim, dkk (dalam Trianto, 2007: 42) struktur tujuan cooperative terjadi jika siswa dapat mencari tujuan mereka bersama sama dengan siswa lain. Tujuan- tujuan pembelajaran ini mencakup tiga jenis tujuan penting, yaitu hasil belajar akademik, penerinaan terhadap keragaman, dan pengembangan keterampilan sosial.

Permainan To The Left merupakan permainan yang bertujuan untuk melatih siswa mengemukakan jawaban, aktif, mandiri dan memahami bahwa sumber informasi tidak hanya dari guru. Peserta permainan ini cocok diaplikasikan pada jenjang pendidikan SD, SMP, dan SMA. Waktu yang dibutuhkan dalam permaina To The Left sekitar 30 menit. Permainan ini sangat cocok dilakukan didalam kelas atau indoor.

Menurut Mel Silberman (dalam Iva Rifa, 2012: 26) berikut beberapa langkah yang harus dilakukan oleh guru sebelum permainan To The Left dimulai:

a. Guru terlebih dahulu meminta siswa untuk membaca materi yang akan didiskusikan.

b. Guru meminta siswa membuat pertanyaan sebanyak 3-5 buah yang berkaitan dengan materi yang dibahas, kemudian mengumpulkannya kepada guru (pertanyaan yang dibuat akan lebih baik jika berbentuk esai).

c. Guru menyiapkan tempat bermain dengan menbuat garis sepanjang 5 meter atau lebih, sesuai dengan kebutuhan menggunakan kapur tulis. Lebih baik guru menyingkirkan kursi, 
lalu membuat garis melintang dari papan tulis ke belakang kelas.

d. Guru membagi siswa menjadi dua kelompok besar, Yaitu kelompok A dan B. Mintalah antar kelompok untuk saling berhadapan dengan garis sebagai pembatasnya.

e. Guru membagi kertas pertanyaan, masing-masing siswa mendapatkan satu kertas.

f. Guru menyampaikan aturan main, yaitu setiap siswa yang berhadapan saling bergantian melontarkan pertanyaan dan menjawab. Bila guru mengatakan merah, maka siswa bergeser ke kiri sebanyak 3 langkah, kuning sebanyak 2 langkah, dan hijau sebanyak 1 langkah (bersifat kondisional, guru bisa menggantikan dengan angka lain atau warna lain). Perhatikan instruksi dengan baik.

g. Guru memberi aba- aba, lalu permainan dimulai setiap 2 menit atau kurang, menginstruksikan untuk berpindah ke kiri.

h. Permainan dihentikan ketika semua pertanyaan sudah selesai atau 15 menit. Tindakan lanjut dari permainan ini adalah guru berkewajiban memimpin diskusi kelas, kemudian membahas apabila ada pertanyaan yang belum

Tabel 1. Data Keterlaksanaan RPP dengan Permainan To The Left.

\begin{tabular}{|c|c|c|c|c|c|}
\hline \multirow{2}{*}{ Tahap } & \multicolumn{2}{|l|}{ Kegiatan } & \multirow[t]{2}{*}{ Waktu } & \multirow[t]{2}{*}{ Karakter } & \multirow[t]{2}{*}{$\mathbf{T} / \mathbf{T T}$} \\
\hline & Guru & Siswa & & & \\
\hline $\begin{array}{l}\text { PENDAH } \\
\text { ULUAN: } \\
\text { Apersepsi }\end{array}$ & $\begin{array}{l}\text { - Memberikan apersepsi kepada siswa } \\
\text { melalui pertanyaan. } \\
\text { Mengapa kita bisa merasakan } \\
\text { gempa bumi? }\end{array}$ & $\begin{array}{l}\text { - Menjawab } \\
\text { pertanyaan }\end{array}$ & 10 & Disiplin . & $\mathrm{T}$ \\
\hline Motivasi & $\begin{array}{l}\text { - Memberikan motivasi dengan } \\
\text { pertanyaan. } \\
\text { Mengapa senar gitar dapat } \\
\text { berbunyi? } \\
\text { - Menyampaikan materi yang akan } \\
\text { dipelajari }\end{array}$ & $\begin{array}{l}\text { - Menjawab } \\
\text { pertanyaan } \\
\text { - } \begin{array}{l}\text { Mendenga } \\
\text { rkan }\end{array}\end{array}$ & 5 & $\begin{array}{l}\text { Menghargai } \\
\text { Pendapat orang } \\
\text { lain. }\end{array}$ & $\mathrm{T}$ \\
\hline INTI & - Menyuruh siswa membaca materi & - Membaca & 15 & & $\mathrm{~T}$ \\
\hline
\end{tabular}

terjawab dan hal-hal penting yang belum tersampaikan.

\section{METODE PELAKSANAAN}

Metode yang digunakan untuk menggali data dalam penelitian ini adalah sebagai berikut.

a. Sumber data: kepala sekolah, guru bidang studi dan siswa karena mampu memberikan informasi yang akurat.

b. Metode observasi: untuk mengamati keterlaksanaan pembelajaran(RPP), aktifitas siswa (aspek afektif dan psikomotorik) dalam pembelajaran.

c. Metode dokumentasi: diperoleh dari nilai UTS, absensi siswa, dan catatan guru, foto PBM.

d. Metode angket: yang diberikan kepada semua siswa untuk mengetahui Respon siswa terhadap pembelajaran dengan pemainan To The Left.

e. Metode wawancara: dilakukan untuk mengetahui tanggapan guru bidang studi dan kepala sekolah terhadap keefektifan pembelajaran To The Left.

\section{HASIL DAN PEMBAHASAN}

\section{Keterlaksanaan RPP}


JEMS (Jurnal Edukasi Matematika dan Sains), 5(2), September 2017- 85

Sri Utami, Frendy Oktaris Whidhayat, R. Bekti Kiswardianta

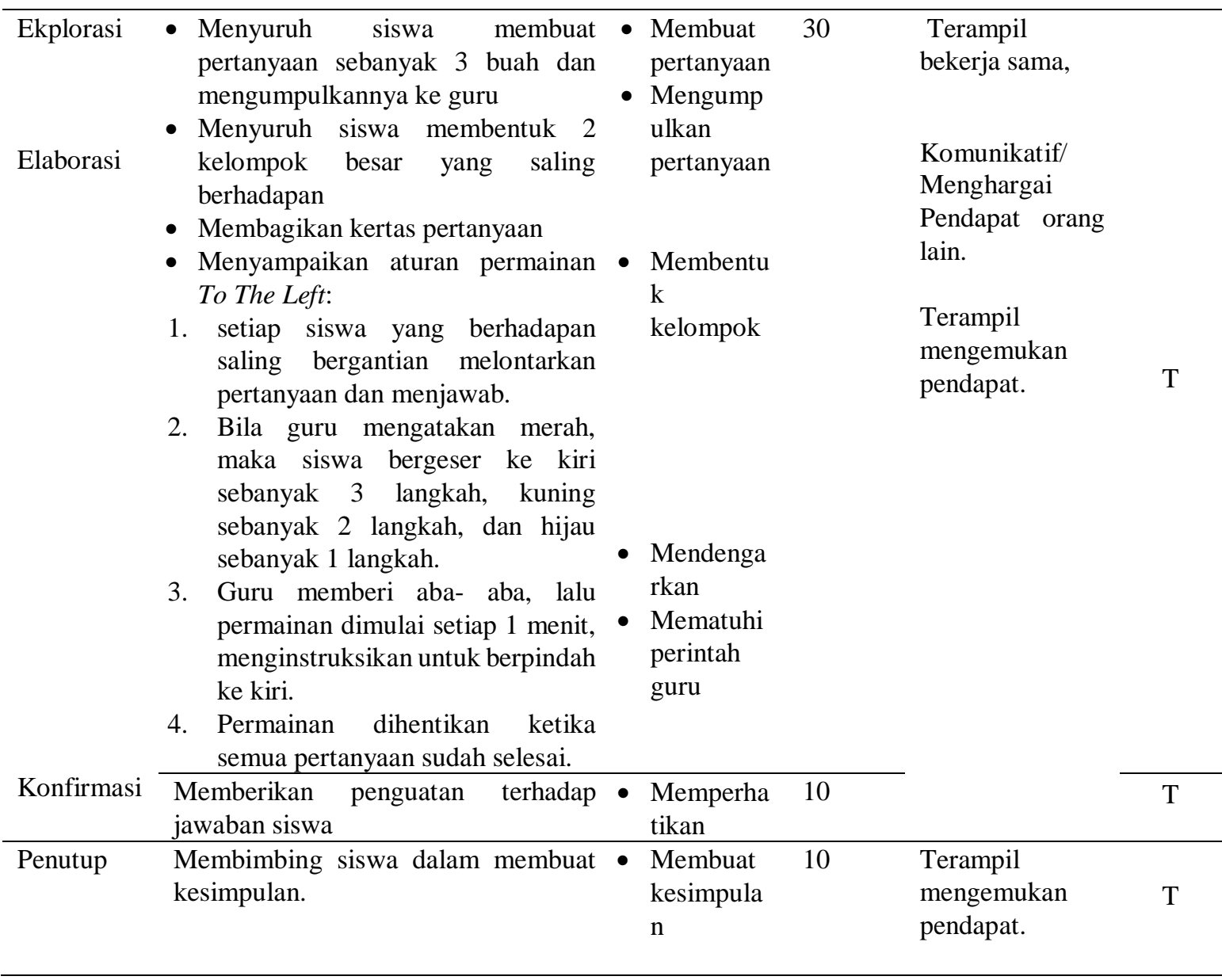

Pada tabel 1 tampak bahwa RPP terlaksana dengan baik, yang dibuktikan dari langkah-langkah permainan To The Left yang terlaksana dengan baik dan benar. Ditinjau dari bentuknya RPP ini masih mengacu pada kurikulum tingkat satuan pendidikan (KTSP). Pemerintah saat ini telah mencanangkan kurikulum K-13, untuk mendukung program tersebut maka akan lebih baik jika RPP yang digunakan pada semester berikutnya disesuaikan dengan format RPP kurikulum K-13. Pada pendahuluan di atas mencakup kegiatan apersepsi dan motivasi dan akan lebih baik jika ditambahkan orientasi atau menyiapkan siswa. Isi apersepsi diperdalam, dan ditambahkan penyampai tujuan pembelajaran pada bagian motivasi, memberitahukan kompetensi dan indikator yang hendak dicapai serta tatacara/metode yang akan dilaksanakan. Kemudian alokasi waktu untuk apersepsi dan penutup sebaiknya cukup 5 menit (Permendikbud no. 65 Thn 2013 Standar Proses). Pada fase konfirmasi sebaiknya ditambahkan diskusi untuk membahas pertanyaan atau hal-hal penting yang belum terjawab pada fase Tanya jawab. Pada fase penutup perlu ditambahkan refleksi proses pembelajaran dan evaluasi materi, pemberian umpan balik dan tindak lanjut berupa tugas, materi pengayaan atau materi untuk pertemuan berikutnya. Hal ini sesuai dengan urutan permaian to the left dalam pembelajaran kooperatif (Mel Silberman dalam Iva Rifa, 2012: 26).

\section{Respon Siswa Terhadap Pembelajaran Dengan Permainan To The Left.}


JEMS (Jurnal Edukasi Matematika dan Sains), 5(2), September 2017- 86

Sri Utami, Frendy Oktaris Whidhayat, R. Bekti Kiswardianta

Tabel 2. Data Jawaban Angket Tertutup dari 28 Responden Tentang Efektifitas Permainan To The Left.

\begin{tabular}{|c|c|c|c|c|c|c|c|c|c|c|c|}
\hline \multirow{2}{*}{$\begin{array}{c}\text { Nomor } \\
\text { Respon } \\
\text { den }\end{array}$} & \multicolumn{10}{|c|}{ Jawaban Responden untuk Item Pertanyaan Nomor: } & \multirow[t]{2}{*}{ Jml. } \\
\hline & 1 & 2 & 3 & 4 & 5 & 6 & 7 & 8 & 9 & 10 & \\
\hline 1 & 4 & 3 & 4 & 2 & 4 & 4 & 4 & 4 & 4 & 3 & 36 \\
\hline 2 & 4 & 4 & 4 & 2 & 2 & 4 & 4 & 3 & 4 & 4 & 35 \\
\hline 3 & 2 & 3 & 4 & 2 & 4 & 3 & 4 & 3 & 3 & 2 & 30 \\
\hline 4 & 4 & 4 & 4 & 4 & 2 & 3 & 4 & 4 & 4 & 4 & 37 \\
\hline 5 & 2 & 3 & 4 & 3 & 3 & 4 & 1 & 4 & 4 & 2 & 30 \\
\hline 6 & 2 & 3 & 4 & 4 & 4 & 4 & 2 & 4 & 4 & 4 & 35 \\
\hline 7 & 2 & 3 & 3 & 2 & 4 & 4 & 3 & 4 & 4 & 3 & 32 \\
\hline 8 & 2 & 4 & 1 & 3 & 3 & 4 & 4 & 4 & 4 & 2 & 31 \\
\hline 9 & 2 & 3 & 3 & 3 & 3 & 4 & 3 & 4 & 4 & 3 & 32 \\
\hline 10 & 2 & 3 & 4 & 2 & 2 & 3 & 4 & 4 & 2 & 2 & 28 \\
\hline 11 & 3 & 1 & 2 & 3 & 2 & 4 & 2 & 4 & 4 & 2 & 27 \\
\hline 12 & 3 & 3 & 4 & 2 & 3 & 3 & 3 & 4 & 3 & 3 & 31 \\
\hline 13 & 2 & 2 & 1 & 3 & 3 & 4 & 1 & 4 & 4 & 2 & 26 \\
\hline 14 & 2 & 3 & 3 & 2 & 2 & 3 & 2 & 3 & 2 & 3 & 27 \\
\hline 15 & 2 & 2 & 2 & 3 & 3 & 4 & 4 & 4 & 3 & 2 & 29 \\
\hline 16 & 2 & 2 & 1 & 1 & 3 & 4 & 3 & 2 & 2 & 4 & 24 \\
\hline 17 & 3 & 3 & 4 & 3 & 3 & 4 & 3 & 4 & 3 & 2 & 32 \\
\hline 18 & 3 & 2 & 2 & 2 & 3 & 2 & 2 & 2 & 3 & 2 & 23 \\
\hline 19 & 3 & 3 & 2 & 3 & 3 & 2 & 3 & 2 & 3 & 2 & 26 \\
\hline 20 & 2 & 2 & 4 & 2 & 3 & 4 & 4 & 3 & 4 & 2 & 30 \\
\hline 21 & 2 & 2 & 2 & 2 & 4 & 3 & 2 & 4 & 4 & 3 & 28 \\
\hline 22 & 2 & 2 & 2 & 2 & 4 & 2 & 3 & 4 & 2 & 2 & 24 \\
\hline 23 & 4 & 4 & 3 & 4 & 4 & 4 & 4 & 3 & 4 & 4 & 38 \\
\hline 24 & 2 & 2 & 3 & 2 & 4 & 4 & 3 & 4 & 3 & 2 & 29 \\
\hline 25 & 4 & 3 & 4 & 2 & 2 & 4 & 3 & 4 & 3 & 2 & 31 \\
\hline 26 & 4 & 3 & 2 & 2 & 1 & 4 & 4 & 3 & 4 & 2 & 33 \\
\hline 27 & 2 & 2 & 2 & 3 & 4 & 4 & 2 & 4 & 1 & 2 & 26 \\
\hline 28 & 4 & 3 & 4 & 2 & 2 & 3 & 3 & 4 & 3 & 3 & 31 \\
\hline Jumlah & & & & & & & & & & & 841 \\
\hline
\end{tabular}

Tabel 3 Data Jawaban Angket Terbuka dari 28 Responden Tentang Permainan To The Left.

Soal Nomor 1: Apakah yang kamu ketahui tentang

Penskoran

No

permainan To The Left ?

\begin{tabular}{lllll} 
& \multicolumn{1}{c}{ Jawaban } & Jml.sis & Sko & Jml. \\
& & wa & r & \\
\hline 1 & $\begin{array}{l}\text { permainan yang menggunakan metode tanya jawab dengan 2 } \\
\text { kelompok yang saling berhadapan }\end{array}$ & 10 & 10 & 100 \\
\hline 2 & $\begin{array}{l}\text { permainan yang menggunakan cara bermain yang } \\
\text { mengharuskan para pesertanya berpindah ke kiri }\end{array}$ & 8 & 9 & 72 \\
\hline 3 & $\begin{array}{l}\text { permainan yang mengandung unsur rasa mandiri, rasa bekerja } \\
\text { sama, menghargai pendapat orang lain dan tidak } \\
\text { membosankan }\end{array}$ & 5 & 8 & 40 \\
\hline 4 & $\begin{array}{l}\text { permainan To The Left merupakan permainan yang } \\
\text { menyenangkan dan membuat suasana menjadi } \\
\text { menyenangkan }\end{array}$ & 3 & 7 & 21 \\
\hline 5 & $\begin{array}{l}\text { permainan yang mudah untuk mengingat pelajaran dan } \\
\text { mudah menerima isi dari pelajaran tersebut }\end{array}$ & 2 & 6 & \\
\hline
\end{tabular}

Soal Nomor 2: Berapa lama waktu yang kamu butuhkan untuk memahami dan dapat melaksanakan permainan To The

Penskoran

No Left dengan baik?

$\begin{array}{lcll}\text { Jawaban } & \begin{array}{c}\text { Jml.si } \\ \text { swa }\end{array} & \text { Skor } & \text { Jml. }\end{array}$


JEMS (Jurnal Edukasi Matematika dan Sains), 5(2), September 2017- 87

Sri Utami, Frendy Oktaris Whidhayat, R. Bekti Kiswardianta

\begin{tabular}{|c|c|c|c|c|}
\hline 1 & $\begin{array}{l}1 \text { sampai } 2 \text { menit dan beralasan bahwa sudah mengerti } \\
\text { langkah-langkahnya dan mudah mengerti }\end{array}$ & 7 & 9 & 63 \\
\hline 2 & $\begin{array}{l}5 \text { sampai } 10 \text { menit dan beralasan sudah memahami isi } \\
\text { pelajaran }\end{array}$ & 11 & 10 & 110 \\
\hline 3 & $\begin{array}{l}10 \text { sampai } 15 \text { menit dan beralasan sudah memahami langkah- } \\
\text { langkah yang harus dilakukan di dalam melaksanakan } \\
\text { permainan To The Left }\end{array}$ & 7 & 8 & 56 \\
\hline 4 & 30 menit untuk memahaminya & 3 & 7 & 21 \\
\hline \multirow[t]{2}{*}{ No } & $\begin{array}{l}\text { Soal Nomor 3: Bagaimana cara dan sikap guru ketika } \\
\text { membimbing dalam pelaksanaan permainan To The Left? }\end{array}$ & \multicolumn{3}{|c|}{ Penskoran } \\
\hline & Jawaban & $\begin{array}{c}\text { Jml.sis } \\
\text { wa }\end{array}$ & $\begin{array}{c}\text { Sko } \\
\mathbf{r}\end{array}$ & Jml. \\
\hline 1 & $\begin{array}{l}\text { sikap dan cara guru ketika membimbing yaitu baik, tegas, dan } \\
\text { sabar }\end{array}$ & 23 & 10 & 230 \\
\hline 2 & $\begin{array}{l}\text { sabar karena guru membimbing para siswa sampai mengerti } \\
\text { dan memehami isi dari pelajaran }\end{array}$ & 3 & 9 & 27 \\
\hline 3 & $\begin{array}{l}\text { menyenangkan karena guru sudah menggunakan permainan } \\
\text { yang menarik }\end{array}$ & 2 & 8 & 16 \\
\hline \multirow{2}{*}{ No } & $\begin{array}{l}\text { Soal Nomor 4: Apa saja kesulitan-kesulitan yang kamu } \\
\text { temui dalam permainan To The Left? }\end{array}$ & \multicolumn{3}{|c|}{ Penskoran } \\
\hline & Jawaban & $\begin{array}{c}\text { Jml.sis } \\
\text { wa }\end{array}$ & $\begin{array}{c}\text { Sko } \\
\mathbf{r}\end{array}$ & Jml. \\
\hline 1 & $\leq 2$ macam kesulitan yang ditemui & 28 & 10 & 280 \\
\hline 2 & $\geq 3$ macam kesulitan yang ditemui & 0 & 9 & 0 \\
\hline \multirow[t]{2}{*}{ No } & $\begin{array}{l}\text { Soal Nomor 5: Apakah permainan To The Left perlu } \\
\text { diterapkan? }\end{array}$ & \multicolumn{3}{|c|}{ Penskoran } \\
\hline & Jawaban & $\begin{array}{c}\text { Jml.sis } \\
\text { wa }\end{array}$ & $\begin{array}{c}\text { Sko } \\
\mathbf{r}\end{array}$ & Jml. \\
\hline 1 & Perlu diterapkan & 28 & 10 & 280 \\
\hline 2 & Tidak perlu diterapkan & 0 & 9 & 0 \\
\hline & Total Jumlah & & & 1328 \\
\hline
\end{tabular}

Nilai 1328 termasuk dalam interval cukup baik dan sangat baik, lebih mendekati sangat baik (Sugiyono, 2010: 143-144).

Hasil angket tertutup dan terbuka diatas dapat disimpulakan bahwa siswa menyukai pembelajaran dengan permaian To The Left. Hal ini sesuai dengan tulisan Hamzah(2007: 15) bahwa metode permainan cocok untuk diterapkan dalam pembelajara biologi karena ada interaksi dan komunikasi aktif antar siswa, serta menimbulkan semangat dan perasaan senang.
2. Tanggapan Guru dan Kepala Sekolah Terhadap Pembelajaran Dengan Permainan To The Left, diambil menggunakan metode wawancara.

Berikut data hasil wawancara dengan guru biologi di MTs 1 Atap Mlarik Ngawi:

1) Apa yang melatar belakangi Ibu menggunakan permainan To The Left? Yang melatar belakangi saya adalah untuk meningkatkan prestasi belajar siswa dan untuk menumbuhkan rasa percaya diri dalam menjawab pertanyaan, sehingga secara tidak langsung dapat mengembangkan 
kemampuan problem solving yaitu kemampuan dalam memecahkan masalah terutama dalam menjawab pertanyaan.

2) Apakah dalam pelaksanaan permainan To The Left dapat mecakup aspek kognitif, afektif dan psikomotorik?

Dapat, karena dalam pelaksanaan permainan To The Left aspek kognitif dapat dilihat dari perilaku siswa dalam menjawab pertanyaan yang diberikan oleh temannya sendiri, aspek afektif dapat dilihat dari perilaku siswa yang yang dapat menghargai pendapat orang lain dan dapat bersosialisasi dengan teman-temannya dengan baik, sedangkan untuk aspek psikomotorik yang sangat berkaitan dengan aktifitas fisik yang diwakili oleh kegiatan berpindah tempat atau posisi yang terjadi pada permainan To The Left.

3) Apakah dengan menggunakan permainan To The Left sudah mencapai tujuan belajar baik ranah kognitif, afektif dan psikomotorik?

Sudah, karena dalam permaianan To The Left perilaku yang diharapkan dapat dicapai oleh peserta didik, seperti pada aspek kognitif perilaku yang digali meliputi pengetahuan dan pemahaman, untuk ranah afektif perilaku yang ditunjukkan siswa seperti dapat bersosialisasi dengan teman-temannya dan dalam aspek psikomotorik meliputi aktifitas siswa yang terutama pada kegiatan fisik.

4) Bagaimanakah respon dari siswa apa bila Ibu menggunakan permainan To The Left?

Responnya senang, hal ini dikarenakan dalam pelaksanaan permainan To The Left ini dapat menumbuhkan kegembiraan dalam pembelajaran.

5) Apakah ada peningkatan nilai, setelah menggunakan permainan To The left?

Ada peningkatan, hal ini dapat dilihat dari hasil nilai ulangan harian yang didapat siswa yang mengalami peningkatan yang signifikan.
6) Apa kelebihan dari permainan To The Left?

Kelebihan dari permainan To The Left adalah siswa menjadi aktif dan dapat menemukan informasi sendiri.

7) Kendala-kendala apa yang Ibu temui dalam penggunaan permainan To The Left?

Kendala-kendala yang ditimbulkan selama ini adalah kadang-kadang siswa ramai di dalam pelaksanaan permainan To The Left.

8) Bagaimanakah cara untuk mengatasi kendala-kendala tersebut?

Untuk mengatasi kendala-kendala itu biasanya saya memberikan hukuman kepada siswa yang ramai seperti memberikan tugas tambahan kepada siswa yang ramai.

9) Apakah permainan To The Left akan tetap diterapkan?

Untuk sementara ini permainan To The Left akan tetap dilaksanakan karena dinilai cukup efektif dalam pembelajaran yang dilakukan dan dapat menimbulkan rasa ketertarikan dalam pembelajaran yang dilakukan, selain itu juga menciptakan keceriaan dan kegembiraan pada siswa.

Berikut data hasil wawancara dengan Kepala Sekolah MTs 1 Atap Mlarik Ngawi:

1) Apakah Bapak pernah mendapat laporan tentang penerapan permainan To The Left dalam pembelajaran?

Pernah, dari Bu Rini yang mengajar IPA kelas VIII

2) Bagaimana pendapat Bapak tentang permainan To The Left yang diterapkan di kelas VIII pada pelajaran biologi?

Permainan To The Left ini cukup menarik, karena dapat menciptakan suasana yang ceria dan menyenangkan sehingga diharapkan mampu meningkatkan hasil belajar siswa.

3) Menurut Bapak, apakah sebaiknya permainan To The Left juga diterapkan pada mata pelajaran yang lain?

Menurut saya, sebaiknya permainan To The Left juga dapat diterapkan pada 
pelajaran lainnya selama hal ini dinilai efektif dalam pembelajaran yang dilakukan oleh guru dan dapat meningkatkan hasil belajar siswa.

4) Apakah permainan ToThe Left akan tetap diterapkan pada tahun pelajaran berikutnya?

Selama hal ini dinilai cukup efektif, sebaiknya dapat tetap diterapkan pada pelajaran selanjutnya.

Hasil wawancara diatas menunjukan bahwa kepala sekolah dan guru secara secara umum berpendapat bahwa permainan To The Left dapat menciptakan suasana yang ceria

Tabel 4. Perolehan Nilai Ulangan Harian Biologi dan Nilai Rapot UTS pada Pelajaran IPA Terpadu yang Dilaksanakan Dengan Menggunakan Permainan To The Left Pada Kelas VIII Tahun Ajaran 2015/ 2016 dengan nilai KKM 75.

\begin{tabular}{|c|c|c|c|c|c|c|c|}
\hline \multirow{2}{*}{ No } & \multirow{2}{*}{ Nama Siswa } & \multicolumn{2}{|c|}{ UH } & \multirow{2}{*}{$\begin{array}{c}\text { Rata- } \\
\text { rata }\end{array}$} & \multirow{2}{*}{ Ket } & \multirow{2}{*}{ UTS } & \multirow{2}{*}{ Ket } \\
\hline & & 1 & 2 & & & & \\
\hline 1 & Anita Nur Halimah & 85 & 80 & 82,5 & $\mathrm{~T}$ & 50 & TT \\
\hline 2 & Bety Sofiani & 85 & 75 & 80 & $\mathrm{~T}$ & 34 & TT \\
\hline 3 & Eka Nur Rahmawati & 95 & 88 & 91,5 & $\mathrm{~T}$ & 89 & $\mathrm{~T}$ \\
\hline 4 & Eko Sudarmono & 30 & - & 30 & TT & 43 & TT \\
\hline 5 & Fatmawati Arifah & 90 & 88 & 89 & $\mathrm{~T}$ & 91 & $\mathrm{~T}$ \\
\hline 6 & Fatkurrohman Nur S. & 70 & 50 & 60 & $\mathrm{TT}$ & 53 & TT \\
\hline 7 & Hanif Gofar Alhafis & 85 & 50 & 67,5 & TT & 68 & TT \\
\hline 8 & Jalis Dwi Muhtohhar & 100 & 100 & 100 & $\mathrm{~T}$ & 100 & $\mathrm{~T}$ \\
\hline 9 & Muslikah Eri Qotimah & 95 & 95 & 95 & $\mathrm{~T}$ & 94 & $\mathrm{~T}$ \\
\hline 10 & Maryanti & 100 & 100 & 100 & $\mathrm{~T}$ & 90 & $\mathrm{~T}$ \\
\hline 11 & Mursid Jony Sapotro & 90 & 88 & 89,5 & $\mathrm{~T}$ & 69 & TT \\
\hline 12 & Mayun Widyawati & 100 & 100 & 100 & $\mathrm{~T}$ & 94 & $\mathrm{~T}$ \\
\hline 13 & Miftakhul Nikmah & 90 & 88 & 89 & $\mathrm{~T}$ & 91 & $\mathrm{~T}$ \\
\hline 14 & Nurul Ratnaningtyas & 100 & 86 & 93 & $\mathrm{~T}$ & 91 & $\mathrm{~T}$ \\
\hline 15 & Rahmad Hakim & 75 & 70 & 72,5 & TT & 64 & TT \\
\hline 16 & Ronaldhina W.D.K. & 60 & 50 & 55 & TT & 76 & $\mathrm{~T}$ \\
\hline 17 & Ratna Meigati & 100 & 95 & 97,5 & $\mathrm{~T}$ & 89 & $\mathrm{~T}$ \\
\hline 18 & Serly Yunia Saputri & 100 & 82 & 91 & $\mathrm{~T}$ & 89 & $\mathrm{~T}$ \\
\hline 19 & Suci Wulandari & 90 & 88 & 89 & $\mathrm{~T}$ & 84 & $\mathrm{~T}$ \\
\hline 20 & Tiara Rias Istiani & 100 & 91 & 95,5 & $\mathrm{~T}$ & 85 & $\mathrm{~T}$ \\
\hline 21 & Vheri Doni Prasetyo & 90 & 78 & 84 & $\mathrm{~T}$ & 70 & TT \\
\hline 22 & Windi Rara Ayu Maruti & 100 & 78 & 89 & $\mathrm{~T}$ & 70 & TT \\
\hline 23 & Imam Prayoga & 90 & 88 & 89 & $\mathrm{~T}$ & 80 & $\mathrm{~T}$ \\
\hline 24 & Irvan Giandy Darmawan & 95 & 88 & 91,5 & $\mathrm{~T}$ & 74 & TT \\
\hline
\end{tabular}

dan menyenangkan sehingga diharapkan mampu meningkatkan hasil belajar siswa, dan permainan ini dapat diterapkan pada pelajaran lainnya karena dianggap cukup efektif. Hal ini diperkuat oleh penyataan dari Suchman (dalam Hamzah: 2007: 15) berpendapat bahwa ilmu bersifat tentatif dan dinamis, karena ilmu berkembang terusmenerus. Sehingga harus ada terobosan baru dalam metode pembelajaran yang digunakan guru, agar siswa tidak bosan dan siswa semakin cepat menangkap isi dari pelajaran.

\section{Nilai Ulangan Harian dan UTS Siswa.}


JEMS (Jurnal Edukasi Matematika dan Sains), 5(2), September 2017- 90

Sri Utami, Frendy Oktaris Whidhayat, R. Bekti Kiswardianta

\begin{tabular}{llccccccc}
25 & Choirul Latifah & 100 & 100 & 100 & $\mathrm{~T}$ & 100 & $\mathrm{~T}$ \\
\hline 26 & Ardi Andy Baharudin Y. & 50 & 30 & 40 & $\mathrm{TT}$ & 81 & $\mathrm{~T}$ \\
\hline 27 & Ilham Langgeng K. & 60 & 50 & 55 & $\mathrm{TT}$ & 67 & $\mathrm{TT}$ \\
\hline 28 & Muhamad Nur & 100 & 95 & 97,5 & $\mathrm{~T}$ & 68 & $\mathrm{TT}$ \\
\hline
\end{tabular}

Dari 28 siswa diperoleh: nilai rata-rata ulangan harian sebanyak 21 siswa $(75 \%)$ tuntas dan 7 siswa (25\%) tidak tuntas, sedangkan nilai UTS 16 siswa $(57,2 \%)$ tuntas dan 12 siswa $(42,8 \%)$ tidak tuntas. Nilai ulangan harian yang diperoleh siswa dapat dikatakan cukup efektif, hal ini dikarenakan permainan To The Left yang dilaksanakan dalam pembelajaran IPA Terpadu kelas VIII berjalan dengan cukup baik, sehingga dapat mempengaruhi hasil belajar terutama nilai ulangan harian siswa pada pokok bahasan yang menggunakan permainan To The Left. Data yang diperoleh dari nilai UTS siswa dapat dikatakan kurang efektif, karena pada ujian UTS tidak semua pokok bahasan yang diujikan ke siswa pada proses pembelajaran gemukakan pendapat.

Tabel 5. Data Skor Aspek Afektif dan Psikomotorik

\begin{tabular}{ccccccc}
\hline \multirow{2}{*}{ Siswa } & \multicolumn{2}{c}{ Skor Aspek yang Diamati } & \multirow{2}{*}{ Siswa } & \multicolumn{2}{c}{ Skor Aspek yang Diamati } \\
\cline { 2 - 3 } & Afektif & Psikomotorik & & Afektif & Psikomotorik \\
\hline 1 & 6 & 5 & 15 & 7 & 7 \\
\hline 2 & 8 & 7 & 16 & 6 & 6 \\
\hline 3 & 7 & 6 & 17 & 8 & 8 \\
\hline 4 & 7 & 7 & 19 & 6 & 7 \\
\hline 5 & 7 & 8 & 20 & 7 & 7 \\
\hline 6 & 8 & 6 & 21 & 6 & 6 \\
\hline 7 & 6 & 7 & 22 & 7 & 7 \\
\hline 8 & 7 & 7 & 23 & 7 & 7 \\
\hline 9 & 7 & 8 & 24 & 7 & 7 \\
\hline 10 & 8 & 8 & 25 & 8 & 6 \\
\hline 11 & 8 & 6 & 26 & 8 & 6 \\
\hline 12 & 7 & 7 & 27 & 7 & 191 \\
\hline 13 & 7 & 7 & 28 & 7 & 7 \\
\hline 14 & 7 & Total dari siswa no: $1-28$ & & 198 & 7 \\
\hline
\end{tabular}

Berdasarkan data di atas dapat diketahui bahwa baik aspek afektif maupun psikomotorik siswa tercapai di atas KKM 75. Hal ini berarti pembelajaran kooperatif dengan permainan To the Left efektif unetuk mencapai aspek afektif(disiplin, komunikatif) dan psikomotorik(keterampilan bertanya dan mengemukakan pendapat). Suasana pembelajaran kondusip dapat tidak semuanya menggunakan permainan To The Left. Hal ini sangat berpengaruh terhadap tingkat pemahaman siswa dan secara tidak langsung sangat berpengaruh terhadap nilai UTS yang diperoleh siswa, dengan kata lain nilai UTS siswa lebih banyak dipengaruhi oleh pembelajaran yang tidak menggunakan permainan To The Left yang belum diketahui tingkat keefektifannya.

\section{Aspek Afektif dan Psikomorik Siswa}

Aspek afektif yang diamati meliputi: A1. disiplin,A2. komunikatif / menghargai pendapat orang lain. Dan Aspek keterampilan atau psikomotorik yang diamati meliputi: P1. keterampilan bertanya, P2. mengemukakan pendapat. 
pembelajaran didefinisikan sebagai cara yang digunakan guru, yang dalam menjalankan fungsinya merupaka alat untuk mencapai tujuan pembelajaran. Metode pembelajaran lebih bersifat prosedural, yaitu berisi tahapan tertentu, sedangkan teknik adalah cara yang digunakan yang bersifat implementatif. Dengan perkataan lain metode yang dipilih oleh masing-masing guru adalah sama, tetapi mereka menggunakan teknik yang berbeda. Sejalan dengan pendapat Sri Esti Wuryani Djiwandono (2004: 361) bahwa permainan yang bukan simulasi dapat juga menambah motivasi untuk belajar. Permainan dengan membentuk tim lebih baik daripada permainan yang dilakukan secara individu, mereka memberikan kesempatan pada teman- teman satu tim untuk saling membantu. Jika semua siswa adalah tim yang mempunyai kemampuan berbeda dan dicampur, maka semua mempunyai kesempatan untuk sukses.

\section{KESIMPULAN}

Pembelajaran kooperatif dengan permainan To The Left pada kelas VII MTs 1 Atap Mlarik Ngawi berjalan dengan efektif ditijau dari segi keterlaksanaan RPP, aspek kognitif, afektif dan psikomotorik siswa, serta Respon siswa, guru dan kepala sekolah.

\section{DAFTAR REVERENSI}

Dimyati \& Midjiono. (2002). Belajar dan Pembelajaran. Jakarta: PT Asdi Mahasatya.

Djiwandono, S. E. W. (2002). Psikologi Pendidikan. Jakarta: PT Gramedia Widiasarana Indonesia.

Fathurrohman, P dan Sutikno, M.S. (2007). Strategi Belajar Mengajar. Bandung: PT Refika Aditama.

Hartinah, S. (2009). Konsep Dasar Bimbingan Kelompok. Bandung: PT Refika Aditama.

Isjoni. (2010). Cooperative Learning. Bandung: Alfabeta.

Nur, M. (2008). Pembelajaran Kooperatif. Surabaya: Pusat Sains dan Matematika Sekolah Unesa.
Rahyubi, H. (2012). Teori-Teori Belajar dan Aplikasi Pembelajaran Motorik. Jawa Barat: Nusa Media.

Riva, I. (2012). Koleksi Games Edukatif di Dalam dan Luar Sekolah. Jogjakarta: Flashbooks.

Sugiyono. (2010). Metode Penelitian Pendidikan. Bandung: Alfebeta.

Sutopo. (2002). Metodologi Penelitian Kualitatif. Surakarta: Sebelas Maret University Press.

Trianto. (2007). Model-Model Pembelajaran Inovatif Berorientasi Konstruktivisme. Jakarta: Prestasi Pustaka.

Uno, H. B. (2007). Model Pembelajaran. Jakarta: PT Bumi Aksara. 